\title{
Concrete Degradation Comparison of Computer Programs for Post-Closure Safety Assessment of Wolsong Low-and Intermediate-Level Radioactive Waste Disposal Facility
}

\author{
월성원자력환경관리센터 폐쇄 후 안전평가 컴퓨터프로그램의 콘크리트 \\ 열화현상에 대한 상호비교
}

Kang-Il Jung, Je-Heon Bang*, Jin Beak Park, and Jeong Hyoun Yoon

Korea Radioactive waste Agency(KORAD), 111 Daedeok-Daero 989, Yuseong-Gu, Daejeon, Korea

정강일, 방제헌*, 박진백, 윤정현

한국원자력환경공단, 대전광역시 유성구 대덕대로 989 번길111

(Received September 10, 2013 / Revised November 8, 2013 / Approved November 20, 2013)

To ensure the reliability of computer programs used for the post-closure safety assessment in the Wolsong LILW Center, the results from MASCOT, SAFE-ROCK and GOLDSIM programs are compared with a problem for degradation. Advantages and disadvantages of each computer programs are individually analyzed. Effects on the individual dose are assessed with each computer programs. MASCOT and SAFE-ROCK showed similar results for ${ }^{129} \mathrm{I}$ and ${ }^{3} \mathrm{H}$. However, GOLDSIM represented different results for ${ }^{129} \mathrm{I}$ and ${ }^{3} \mathrm{H}$. It is analyzed further and compared with the fluxes in each barrier of the disposal system. Througout the benchmarking testing of the computer program, the limitation of computer program can be continuously found out for the mature post-closure safety of Korean radwaste disposal system.

Keywords: Low- and Intermediate-Level Radioactive Waste, Final Disposal, Post-closure safety assessment, MASCOT, SAFE-ROCK, GOLDSIM

우리나라 중저준위 방사성폐기물 최종 처분시설인 월성원자력환경관리센터의 폐쇄 후 안전평가 컴퓨터 프로그램의 신뢰성 확보를 위해 MASCOT와 검증프로그램으로 SAFE-ROCK와 GOLDSIM을 선정하여 정상시나리오에 대하여 안전평가를 수행 하였다. 각 프로그램의 장단점을 비교/분석하였으며, 각 프로그램 별 구획 간의 선량 및 누출량을 평가하였다. 그 중 방사성 핵종 ${ }^{129} \mathrm{I}$ 와 ${ }^{3} \mathrm{H}$ 가 MASCOT와 SAFE-ROCK 프로그램에서는 비슷한 경향을 보여주었지만, GOLDSIM 프로그램에서는 상이한 결과를 나타냈다. 이는 각 프로그램의 근계지역 내 핵종이동방정식의 해석과정의 차이와 개별 프로그램의 한계로 인해 다른 결과값을 보여주는 것으로 분석되었다. GOLDSIM 프로그램의 경우, 선원항 구획에서 초기 핵종누출량은 time-scale에 민감 하게 반응한다는 사실도 확인할 수 있었다. 안전평가 프로그램은 처분환경에서 발생하는 핵종거동 및 이동에 대한 실제현 상을 예측하기 위해 모델링을 거치지만, 전산프로그램의 특성과 실제현상에 대한 데이터가 제한적이므로 결과에 차이가 발 생하게 된다. 이러한 차이점은 다양한 프로그램을 이용한 결과와 상호비교를 통해 알아내며 그 원인을 지속적으로 분석하 는 연구개발과정을 필요로 하고 있다.

중심단어 : 중저준위방사성폐기물, 처분시설, 월성원자력환경관리센터, 폐쇄후안전평가, MASCOT, SAFE-ROCK, GOLDSIM

* Corresponding Author.

Je-Heon Bang, Korea Radioactive waste Agency(KORAD), E-mail: jhbang@korad.or.kr, Tel: +82.42.601.5326 
Kang-Il Jung. et al : Concrete Degradation Comparison of Computer Programs for Post-Closure Safety Assessment of Wolsong Low- and Intermediate-Level Radioactive Waste Disposal Facility

\section{1.서 론}

우리나라는 원자력발전소를 포함한 원자력시설이 도입 된 이후 원자력시설에서 발생된 중저준위방사성폐기물의 영구처분시설로서 월성원자력환경관리센터(Wolsong Lowand Intermediate- Level Radioactive Waste Disposal Facility, 이하 월성처분시설)를 2008년 7월 건설 및 운영허가를 취득한 이후 건설에 착수하여 2014년 6월 완공을 목표로 하 고 있다. 월성처분시설은 경북 경주시 양북면 봉길리 일원에 약 210 만 $\mathrm{m}^{2}$ 의 면적에 총 80 만 드럼의 중저준위 방사성폐기 물의 처분을 계획하고 있으며, 1 단계로 중저준위 방사성폐기 물 10만 드럼을 동굴처분방식으로 건설하고 있다. Fig. 1과 Fig. 2 는 각각 월성처분시설의 조감도와 시설의 폐쇄 후 처

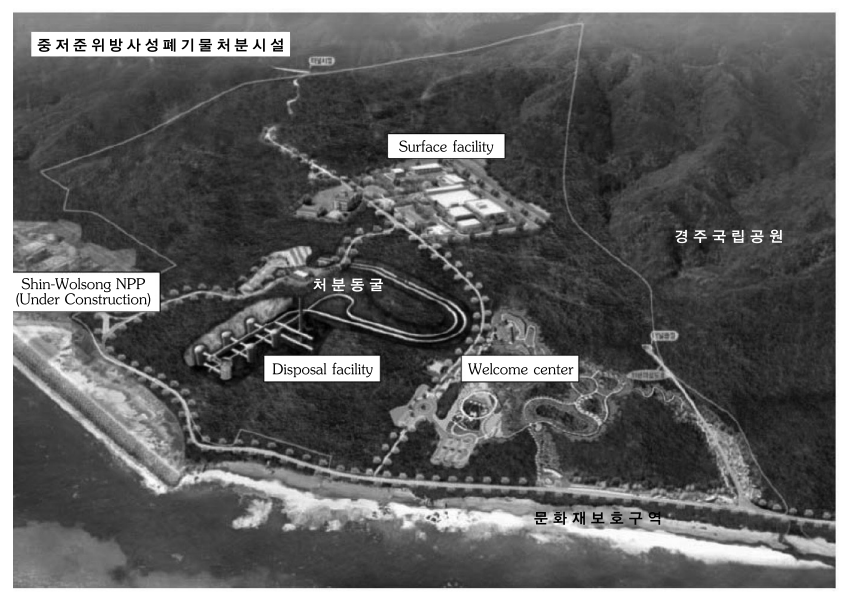

Fig. 1. Bird eye's view of Wolsong Low- and Intermediate-Level Radioactive Waste Disposal Center.

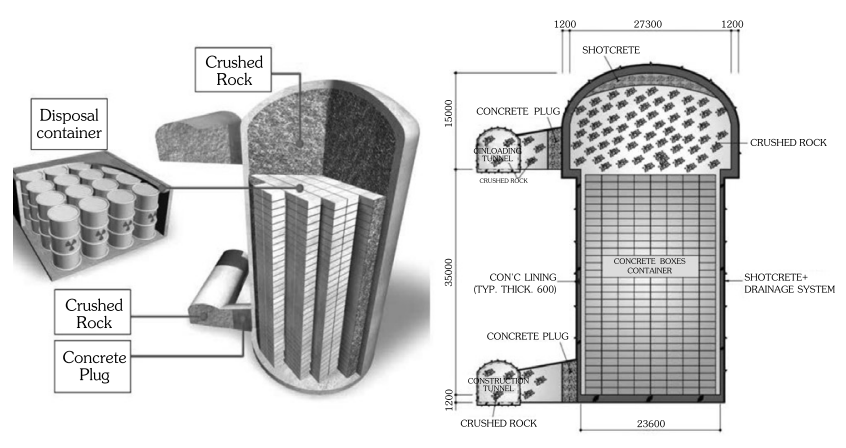

Fig. 2. Conceptual Plan of Disposal Facility Closure for of Wolsong Low- and Intermediate-Level Radioactive Waste Disposal Center.
분개념을 나타내었다.

월성처분시설은 원자력안전위원회 관련 고시[1-2]에 따 라 시설의 건설 및 운영을 위한 허가신청서류뿐만 아니라 처 분시설 완공 이후에도 운영 중 주기적으로 안전평가를 수행 하도록 규정하고 있다.

이에 따라 월성처분시설에 대한 안전평가를 수행하기 위 해 IAEA ISAM 방법론[3]에 기반으로 처분시설 안전평가 시 나리오를 위한 FEP(Features, Events and Processes)을 작성 하여 평가 시나리오를 선정한 후, 그에 따른 평가가정과 평 가도구를 설정하였다. 월성처분시설 안전평가에 적용되는 입력변수들은 개별 실험 및 문헌결과들을 통해 확보하고 컴 퓨터 프로그램들로 구성된 평가체계를 이용하여 수행하였 다[4-7].

월성처분시설은 최초 건설 및 운영허가 신청을 위한 폐 쇄 후 안전평가에서 MASCOT[8]라는 컴퓨터 프로그램으로 지하매질에서 방사성핵종이동 해석을 위해 사용하였다. 핵 종이동 해석에는 월성처분시설의 주요 공학적방벽인 콘크 리트사일로의 열화 전후의 핵종재고량, 지하암반에서의 지 하수 Darcy 속도, 지하매질의 분배계수 등을 반영하였다. 특 히, 콘크리트사일로 방벽의 열화시점을 기준으로 열화 전과 열화 후의 핵종이동을 구분하여 평가하고 질량보존을 고려 한 최종평가결과를 제시하는 방법으로 평가를 수행하였다.

이러한 방법은 MASCOT[8] 프로그램 적용의 한계로 인 한 것으로 콘크리트사일로 방벽의 점진적 열화현상을 프로 그램 내에서 반영하지 못하는 문제점에서 비롯되었다. 열화 시점 이전과 이후 콘크리트사일로 방벽의 변화된 두 개 특성 값을 입력하게 되여 연속적인 열화현상을 컴퓨터 프로그램 에 적용할 수 없으며, 이에 따른 예측결과에 대한 불확실성 을 포함하게 된다.

본 논문에서는 이러한 문제점에 대해 컴퓨터프로그램 예측결과의 불확실성 저감 및 월성처분시설의 안전성증진 을 위해 기존 MASCOT[8] 프로그램 외에 처분시스템 내에 서의 질량전달을 모사하는 GOLDSIM[9]프로그램과 SAFEROCK[10]프로그램을 이용하여 콘크리트사일로 방벽의 열 화현상에 대한 핵종이동 예측결과를 상호비교하고 그 결과 를 고찰하고자 한다.

\section{2. 처분시설 안전평가}

\section{1 처분시설 안전평가 개요}


Kang-Il Jung. et al : Concrete Degradation Comparison of Computer Programs for Post-Closure Safety Assessment of Wolsong Low- and Intermediate-Level Radioactive Waste Disposal Facility

방사성폐기물 처분시설의 폐쇄 후 안전평가는 다른 원자 력시설과는 달리 시설의 폐쇄 후 먼 미래에 궁극의 목표를 두 며, 운영 중 단계뿐만 아니라 장기적 관점에서 부지선정, 공 학적 방벽 및 제도적 관리의 설정 등 처분안전확보를 위한 단 계적 대책을 필요로 한다.

그로 인해 처분시설의 설계, 건설, 운영, 폐쇄, 제도적 관 리를 포함한 처분사업의 각 단계에 있어 제반 안전확보 대책 의 타당성 제시를 위한 안전평가를 실시하게 된다. 처분시설 의 운영종료 후에도 시설특성에 따라 100 년 이상의 제도적 관리기간을 설정하여 시설의 부지 및 환경감시, 시설의 유지 보수, 출입통제, 토지 사용제한 등 방사성물질과 인간의 접 촉을 제한하기 위한 활동을 포함하는 장기적 관점의 안전확 보 대책을 요구하고 있다.

우리나라 원자력안전위원회 고시[11]에서는 처분시설의 폐쇄 후 제도적 관리기간을 포함하여 1,000 년 이상의 기간 동안 방사성물질에 의한 피폭가능성이 있는 자연현상에 대 하여 인간건강과 환경보호를 위해 처분시설의 성능목표치로 서 연간 $0.1 \mathrm{mSv}$ 이하를 제시하고 있으며, 안전평가를 통해 방사성폐기물 처분시설이 인간에게 미치는 영향을 종합적으 로 평가하도록 요구하고 있다.

\section{2 처분시설 안전평가 대상}

방사성폐기물 처분시설의 안전평가는 현재와 미래에 가능한 상황을 고려하여 선원항(Source Term), 인공방벽 (Engineered Barrier), 자연방벽(Natural Barrier) 및 생태계 (Biosphere)로 구분되는 처분시스템의 통합성능을 평가하 게 된다. 그러나 현재 인간의 능력으로는 먼 미래의 시점에 개별 그리고 전체 처분시스템이 어떻게 변화할지에 대한 지 식과 정보가 부족하므로 해석 내용과 결과에 불확실성을 내 포하게 된다[3].

처분시설 안전평가의 불확실성 관리방법으로 처분시스 템에서 예상되는 시나리오의 도출과 시나리오에 대한 평가 결과의 분석방법이 이용되어 왔다. 처분시설 안전평가를 위 한 시나리오 도출은 처분시설에서 발생이 가능한 적절한 요 인들(FEP목록이라 칭함)을 포괄적으로 파악하고 논리적으 로 목록화하는 방법이 사용된다[6]. FEP목록은 안전평가의 대상으로 고려되는 처분시스템 특성과 함께 폐쇄 후 안전평 가를 위한 시나리오를 설정하는데 사용된다.

컴퓨터프로그램의 상호비교의 대상이 되는 안전평가 시 나리오는 지하 처분시설 주변의 위치한 암석/시멘트 혼합재

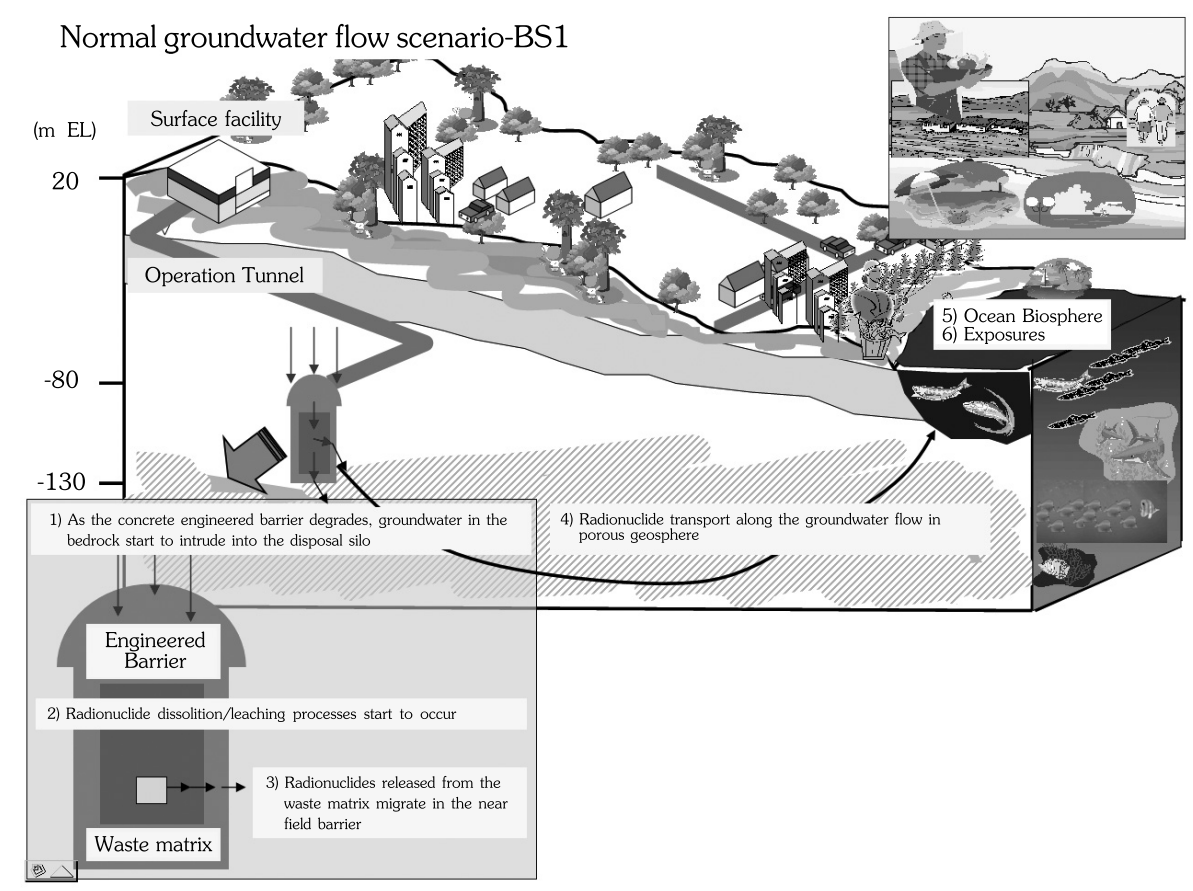

Fig. 3. Safety Assessment Normal Scenario for Computer Program Benchmarking [BS-1][4]. 
Kang-Il Jung. et al : Concrete Degradation Comparison of Computer Programs for Post-Closure Safety Assessment of Wolsong Low- and Intermediate-Level Radioactive Waste Disposal Facility

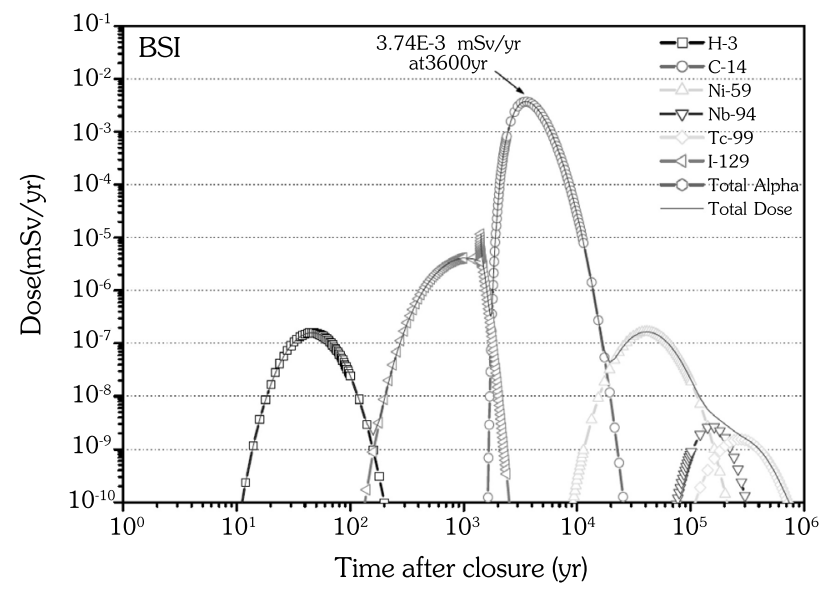

Fig. 4. Example of result on benchmarking scenario by MASCOT computer program.

와 콘크리트 사일로 인공방벽의 시간에 따른 열화현상으로 인하여 인공방벽 외부의 지하수가 침투하여 방사성폐기물 포장용기와 접촉에 따른 핵종용해 현상을 고려한다. 핵종용 해 현상에 따른 핵종누출 현상은 콘크리트사일로 인공방벽 내부의 뒷채움재와 콘크리트사일로 방벽을 통해 방사성핵종 이동 현상을 통해 인공방벽을 벗어나게 된다. 인공방벽에서 누출된 방사성핵종은 처분부지에 존재하는 지하수유동에 의 해 자연방벽을 이동하며 생태계에 도달한 방사성물질은 생 태계 먹이사슬을 통해 거주하는 개인에게 방사선피폭 현상 이 발생하는 것으로 고려하였다[4]. 컴퓨터프로그램의 상호 비교를 위한 안전평가 시나리오 개념을 Fig. 3 에 제시하였다.

\section{3 처분시설 안전평가 결과}

Fig. 3에 제시한 월성처분시설 안전평가 시나리오에 대 한 폐쇄 후 안전평가결과를 Fig. 4에 나타내었다. 안전평가 에서는 월성처분시설의 건설 및 운영허가시 사용된 입력데 이터를 적용하였으며, 공학적사일로 방벽의 자연적열화와 처분시설 폐쇄후 지하수 재포화를 고려한 보수적인 가정들 을 적용하였다. 평가결과로 주어진 $3.74 \mathrm{E}-3 \mathrm{mSv} / \mathrm{yr}$ 는 원자 력위원회 관련고시[11]에 제시된 성능목표치인 $1.0 \mathrm{E}-1 \mathrm{mSv} /$ $\mathrm{yr}$ 를 만족하고 있다.

\section{3. 처분시설 안전평가 컴퓨터프로그램}

\subsection{MASCOT 프로그램}

MASCOT 프로그램[8]은 영국 AEA 사에서 개발한 방사 성폐기물 처분시설의 안전평가 프로그램이다. 이 프로그램 은 3차원 지하매질에서의 방사성핵종이동을 평가하는데 수 치적인 Laplace 역변환법을 이용하여 핵종이동 현상을 1 차 원으로 평가한다. MASCOT는 단위 방벽들을 통한 핵종이동 현상을 모사하기 위하여 각 단위 방벽들을 개별 모델로 표현 한다. 각 방벽에서는 핵종이동 현상을 모델별 응답함수로 설 정하여 다음 방벽의 출력함수로 전달하는 방법을 사용하며, 방사성물질에 의한 선량평가는 최종 생태계에서 방사선 피 폭선량 또는 위험도로 평가된다.

MASCOT 프로그램[8]에서 질량보존을 고려하면서 콘크 리트사일로 방벽의 열화를 반영하기 위해서 열화 후 핵종재 고량에 대하여 열화시점 이전기간 동안 근계지역에서 누출 된 핵종질량을 예측하여 차감하는 방법을 이용하였다. 예를 들면, 10 이라는 초기재고량이 열화시점까지 4가 누출되고 6 이 남는다면, 열화후의 재고량에서는 열화시점까지의 붕괴 를 반영한 재고량에 $60 \%$ 만 반영하여 열화후의 결과값은 예 측한다. 선원항영역의 방사성핵종의 시간에 대한 질량보존 방정식은 식 (1)과 같이 제시된다[8].

$$
\frac{d M_{n}(t)}{d t}=-\lambda_{n} M_{n}(t)+-\lambda_{n-1} M_{n-1}(t)-k_{n} M_{n}(t)
$$

여기서 $\mathrm{M}_{\mathrm{n}}(\mathrm{t})$ 은 선원항 영역에서 시간 $\mathrm{t}$ 에서 방사성핵종 $\mathrm{n}$ 의 질량 $[\mathrm{mol}]$ 을 나타내며 $\lambda$ 는 핵종 붕괴상수 그리고 $\mathrm{k}_{\mathrm{n}}$ 은 핵종 $\mathrm{n}$ 의 침출율을 나타낸다.

\subsection{1 선원항}

MASCOT 프로그램[8]에서 사용되는 선원항모델은 단순 침출 모델과 용해도제한모델로 나누어진다. 단순침출 모델 은 방사성폐기물 고화체 내부에서 고체부분에 있던 방사성 핵종이 공극수를 이루고 있는 용액에 녹아 나올 때 흡착능에 근거한 분배계수에 의해 일정한 비율로 침출된다고 가정한 단순한 모델로써 식 (2)과 같은 지배 방정식으로 표현하였다. $\mathrm{k}_{\mathrm{n}}$ 는 핵종 $\mathrm{n}$ 의 침출율을 나타낸다.

$$
\mathrm{k}_{\mathrm{n}}=\frac{\mathrm{qA}}{\mathrm{v}\left(\varnothing+\beta \rho \mathrm{K}_{\mathrm{n}}\right)}
$$

여기서, q는 방사성폐기물 고화체를 통과하는 지하수의 유속 $[\mathrm{m} / \mathrm{yr}]$ 이며, $\mathrm{A}$ 는 선원항 영역의 면적 $[\mathrm{m}], \mathrm{V}$ 는 선원항 영역의 체적 $\left[\mathrm{m}^{3}\right]$ 이며, $\varnothing$ 는 선원항의 공극률 [-] 그리고 $\beta \rho$ 
Kang-Il Jung. et al : Concrete Degradation Comparison of Computer Programs for Post-Closure Safety Assessment of Wolsong Low and Intermediate-Level Radioactive Waste Disposal Facility

$\mathrm{k}_{\mathrm{n}}$ 는 선원항의 흡착능 $\left[\mathrm{m}^{3} / \mathrm{kg}\right]$ 을 나타내며, $\beta$ 는 흡착이 가능 한 고화체 물질의 분율, $\rho$ 는 밀도, $\mathrm{K}_{\mathrm{n}}$ 는 핵종 $\mathrm{n}$ 의 분배계수 를 나타낸다.

용해도제한 모델에서는 지연율(retardation rate)과 용해 도 제한치(solubility limit, $\mathrm{mol} / \mathrm{m}^{3}$ )를이용한 선원항 모델로 서 이 두 입력변수에 따라 근계지역 방사성핵종누출에 미치 는 영향이 크다. 그러나, 월성처분시설의 건설 및 운영허가 를 위한 폐쇄 후 안전평가에서는 지하수가 폐기물고화체와 접촉시 모든 핵종이 순간적으로 용해되는 보수적 가정을 적 용하였다.

\subsection{2 근계 - 원계지역}

근계 및 원계지역의 방사성핵종 이동현상은 다공성매질 에서 이류, 확산, 분산, 평형상태의 핵종흡착과 방사성붕괴 및 생성(ingrowth) 등을 고려하고 있다. 지하 다공성매질에 서 지하수유동 현상을 통한 방사성핵종농도 $\left(\mathrm{C}_{n}\right)$ 의 지배방정 식은 식 (3)과 같다.

$$
\begin{aligned}
R_{n} \frac{\partial C_{n}}{\partial t}=- & v \frac{\partial C_{n}}{\partial t}+D \frac{\partial^{2} C_{n}}{\partial x^{2}}-\lambda_{n} R_{n} C_{n} \\
& +\lambda_{n-1} R_{n-1} C_{n-1}
\end{aligned}
$$

여기서 $\mathrm{R}_{\mathrm{n}}$ 은 핵종 $\mathrm{n}$ 에 대한 지연인자(retardation coefficient) [-]이고, $\mathrm{v}$ 는 지하수의 유동속도 [m/yr], D는 분산계 수 $\left[\mathrm{m}^{2} / \mathrm{s}\right]$ 이다. MASCOT를 이용한 월성처분시설의 건설 및 운영허가를 위한 폐쇄 후 안전평가에서는 이류와 함께 분산 계수를 이용하여 평가하며, 분산계수가 유효확산계수와 방 벽의 길이분산계수의 $1 / 10$ 을 합한 후에 유속을 곱하여 모델 링에 반영하였다.

\subsection{3 생태계}

월성처분시설의 건설 및 운영허가를 위한 폐쇄 후 안전 평가에서 생태계 단위모델은 자연방벽과 생태계 접점의 핵 종별 누출량[Bq/yr]을 AMBER 컴퓨터 프로그램[9]을 이용한 생태계 평가모델에서 도출된 선량환산인자[Sv/Bq]를 이용하 여 연간피폭선량 $[\mathrm{Sv} / \mathrm{yr}]$ 을 도출하였다.

\subsection{4 프로그램 구조}

MASCOT 프로그램에서 적용한 핵종재고량, 선원항, 근 계/원계 그리고 생태계를 이용한 전체 폐쇄 후 안전평가 구 조를 Fig. 5에 나타내었다. MASCOT 프로그램을 이용한 전 체 폐쇄후 안전평가는 평가 시나리오에서 고려한 핵종이동 현상에 따라 개별 사일로에 처분된 폐기물의 종류별 선원항

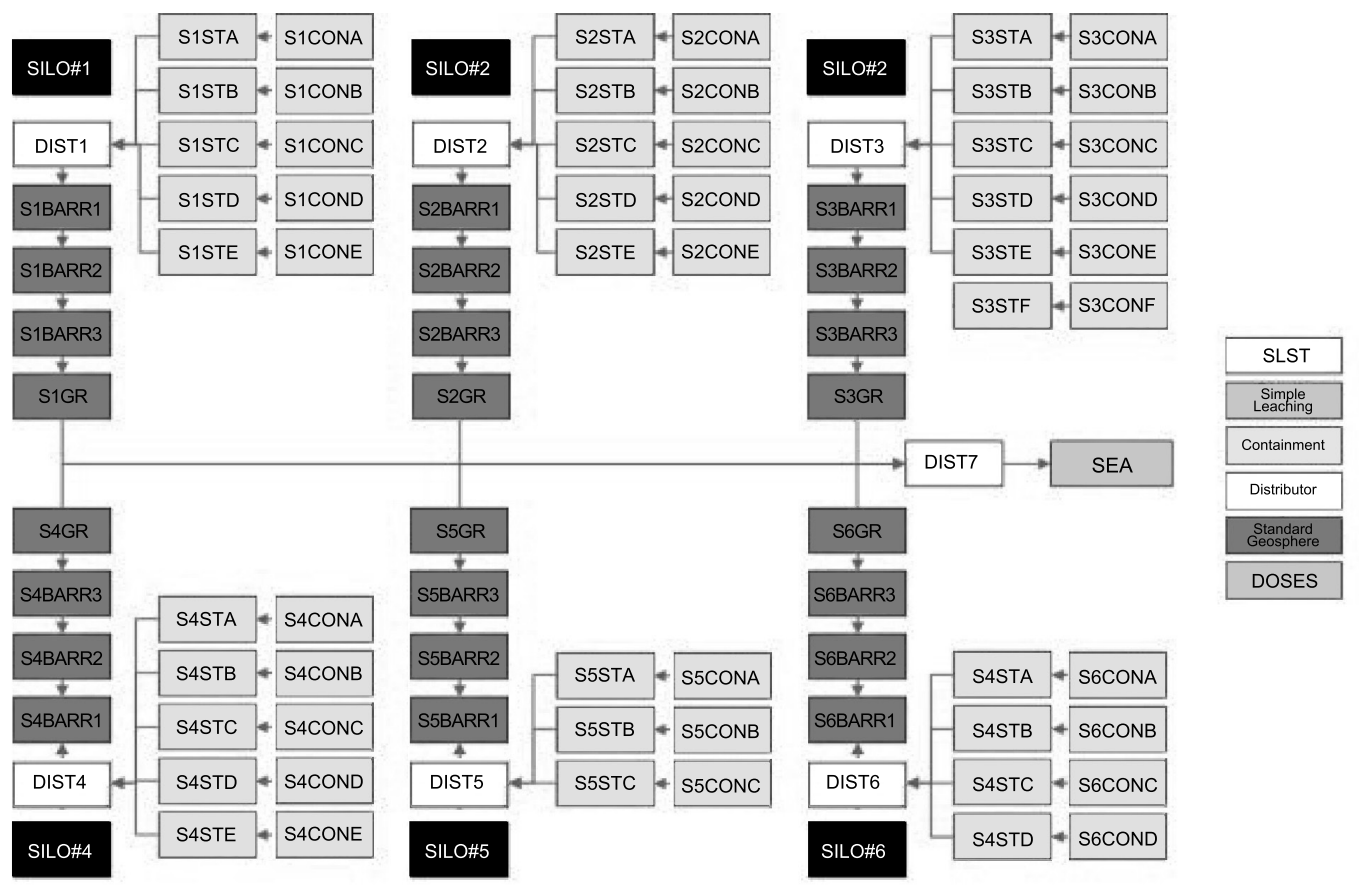

Fig. 5. Modeling Structure of MASCOT Computer Program. 
Kang-Il Jung. et al : Concrete Degradation Comparison of Computer Programs for Post-Closure Safety Assessment of Wolsong Low- and Intermediate-Level Radioactive Waste Disposal Facility

을 적용하였다. 단순침출모델(Simple leaching)과 용해도 제 한모델(Solubility Limited Source Term)을 적용하여 공학적 방벽과 자연방벽 생태계를 통해서 방사성핵종이 이동되는 구 조를 가지고 있으며 각각의 단위 방벽들은 단위 모듈로 표현 하여 핵종이동 현상을 응답함수로 설정하여 다음 방벽의 출 력함수로 전달하는 방법이다.

\subsection{GOLDSIM 프로그램}

GOLDSIM은 GOLDSIM Technology Group에 의해 개발 상 용화된 범용 시뮬레이션 패키지로 유동이 존재하는 시스템 을 모사하는 경우라면 어느 경우에나 사용자 편의성을 지닌 유용하게 그 모델링에 적용될 수 있는 개발도구 프로그램이 다. 특히, 사용자에게 편리한 그래픽 유저 인터페이스와 함 께 객체 지향적 프로그래밍 방식으로 방사성폐기물 처분시 설의 폐쇄후 안전평가를 수행하는 국가에서 사용되고 있다.

\subsection{1 선원항}

GOLDSIM는 다양한 선원항 모델을 표현할 수 있지만 MASCOT와 비교하기 위하여 동일한 폐기물 종류에 따른 선 원항 모델인 용해도제한모델과 단순침출 모델로 나누어서 적용하였다.

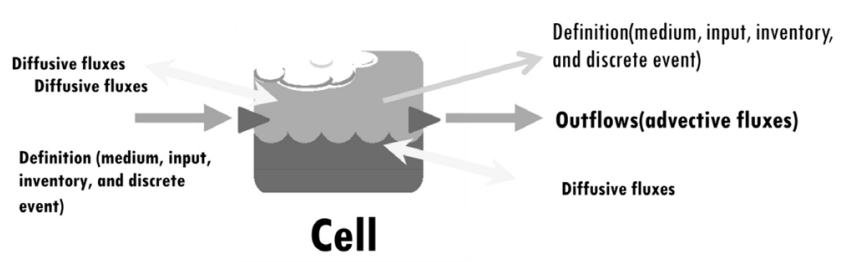

Inflows (advective fluxes of both fluids and solids)

Fig. 6. Cell pathway of GOLDSIM Program.

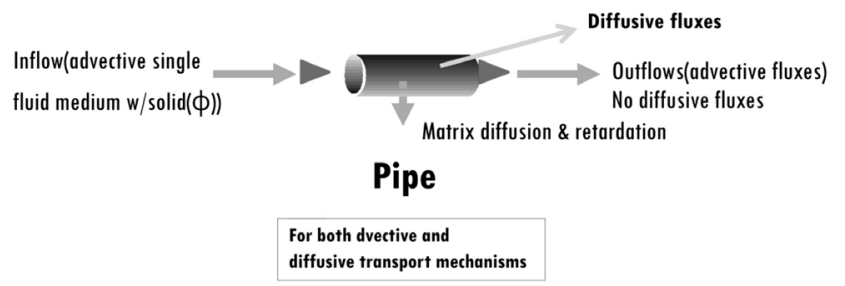

Fig. 7. Pipe pathway of GOLDSIM Program.

\subsection{2 근계지역}

GOLDSIM에서는 방사성핵종의 질량이동을 모사 하기 위해서는 주로 Cell pathway와 Pipe pathway를 사용한다. Cell pathway는 확산과 이류에 의한 물질이동을, Pipe pathway는 이류와 분산에 의한 물질이동을 기술하는데 적합하 다. 따라서, 근계지역에서는 주로 확산과 이류가 지배적으로 이루어지기 때문에 Fig. 6처럼 Cell pathway를 이용하여 모 델링을 하였다. Cell 내의 핵종질량보존식은 식 (4)과 같이 시 간에 대하여 1차 상미분방정식으로 표현된다[12-13].

$$
\begin{gathered}
\frac{\mathrm{dm}_{\mathrm{i}}^{\mathrm{s}}}{\mathrm{dt}}=-\mathrm{m}_{\mathrm{i}}^{\mathrm{s}} \lambda^{\mathrm{s}}+\sum_{\mathrm{p}=1}^{\mathrm{N}^{\mathrm{p}}} \mathrm{m}_{\mathrm{ip}} \lambda^{\mathrm{p}} \mathrm{f}_{\mathrm{p}}^{\mathrm{s}} \mathrm{S}^{\mathrm{p} \rightarrow \mathrm{s}}\left(\frac{\mathrm{W}^{\mathrm{s}}}{\mathrm{W}^{\mathrm{p}}}\right) \\
+\sum_{\mathrm{c}=1}^{\mathrm{N}_{1}}-\phi_{1=\mathrm{i}}^{\mathrm{s}}+\mathrm{S}_{\mathrm{i}}^{\mathrm{s}}
\end{gathered}
$$

여기서 $m_{i}^{s}$ 는 Cell I의 핵종질량 $[\mathrm{kg}], \mathrm{p}$ 는 모핵종을 의미, $\lambda^{\mathrm{s}}, \lambda^{\mathrm{p}}$ 는 붕괴상수[1/yr], $\mathrm{N}^{\mathrm{p}}$ 는 모핵종 원자량, $\mathrm{f}_{\mathrm{p}}^{\mathrm{s}}$ 는 붕괴에

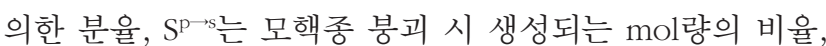
$\mathrm{W}^{\mathrm{s}}, \mathrm{W}^{\mathrm{p}}$ 는 핵종와 모핵종의 분자량 $[\mathrm{kg} / \mathrm{mol}], \mathrm{N}_{\mathrm{l}}$ 는 Cell i로부 터 이동하는 질량누출량 수, $\phi_{1 \rightarrow i}^{s}$ 는 이류나 확산을 통해 유 입된 누출량 비율 $[\mathrm{kg} / \mathrm{yr}], \mathrm{S}_{\mathrm{i}}^{\mathrm{s}}$ 는 외부로부터 유입되는 유입률 $[\mathrm{kg} / \mathrm{yr}]$ 이다.

\section{2 .3 원계지역}

원계지역 모델에서는 이류가 지배적이므로 Fig. 7처럼 Pipe pathway를 사용하여 모델링을 하는데 Pipe pathway 를 나가는 핵종누출량은 시간과 Pipe출구에서 지하수에 용 해된 농도의 함수로 아래의 식 (5)와 같이 표시된다.

$$
\phi^{s}=\left(1+C^{s s} K_{s s}^{s}\right) Q c^{s}-\left.\left(D_{s}+\alpha Q\right) \frac{\partial c^{2}}{\partial x}\right|_{X=L}
$$

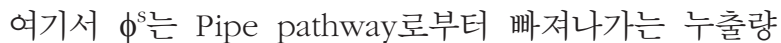
$[\mathrm{kg} / \mathrm{yr}], \mathrm{C}^{\mathrm{SS}}$ 는 균열에서 오염물질의 농도 $\left[\mathrm{kg} / \mathrm{m}^{3}\right], \mathrm{Q}$ 는 유 동로의 유동량 $\left[\mathrm{m}^{3} / \mathrm{yr}\right], \mathrm{K}_{\mathrm{ss}}^{\mathrm{s}}$ 는 오염물질과 유체간의 흡착계 수 $\left[\mathrm{m}^{3} / \mathrm{yr}\right], \mathrm{D}_{\mathrm{s}}$ 는 유효확산계수 $\left[\mathrm{m}^{2} / \mathrm{yr}\right] \alpha$ 는 유동로의 분산도 $[\mathrm{m}], \mathrm{L}$ 는 유동로의 길이 $[\mathrm{m}], \mathrm{x}$ 는 유동로의 거리 $[\mathrm{m}], \mathrm{c}^{\mathrm{s}}$ 는 유동로의 균열내의 용해된 농도 $\left[\mathrm{kg} / \mathrm{m}^{3}\right]$ 이다. 이는 아래 의 식 (6)으로 기술할 수 있다. 
Kang-Il Jung. et al : Concrete Degradation Comparison of Computer Programs for Post-Closure Safety Assessment of Wolsong Low- and Intermediate-Level Radioactive Waste Disposal Facility

$$
\begin{aligned}
\frac{a c_{i m}^{s}}{a t}= & \left(\frac{D_{i m}^{s}}{\theta_{i m} R_{i m}^{s}} \frac{\partial^{2} c_{i m}^{s}}{\partial z^{2}}+\frac{D_{i m}^{s}}{\theta i m R_{i m}^{s} R_{i m}} \frac{\partial A_{i m}}{\partial z} \frac{\partial c_{i m}^{s}}{\partial z}\right) \\
& -\left(c_{i m}^{s} \lambda^{s}+\sum_{p=1}^{N^{p}} c_{i m}^{p} \lambda^{p} S_{p \rightarrow s} \frac{W^{s}}{W^{p}} \frac{R_{i m}^{p}}{R_{i m}^{s}}\right)
\end{aligned}
$$

여기서 $\mathrm{D}_{\mathrm{im}}^{\mathrm{s}}$ 는 균열에서의 유효확산도 $\left[\mathrm{m}^{2} / \mathrm{yr}\right], \theta_{\mathrm{im}}$ 는 균열 의 공극률, $\mathrm{R}_{\mathrm{im}}^{\mathrm{p}}, \mathrm{R}_{\mathrm{im}}^{\mathrm{s}}$ 균열내의 핵종과 모핵종의 지연인자, $\mathrm{A}_{\mathrm{im}}$ 는 균열의 단위거리당 확산면적 $\left[\mathrm{m}^{2}\right]$ 이다.

\subsection{4 생태계}

GOLDSIM에서는 생태계 모델링을 평가할 수 있지만, MASCOT와 동일하게 평가하기 위해서 각 핵종별 단위 누출 량 $[\mathrm{Bq} / \mathrm{yr}]$ 을 생태계 평가프로그램으로부터 평가된 선량환산 인자 $[\mathrm{Sv} / \mathrm{Bq}]$ 를 이용하여 선량 $[\mathrm{Sv} / \mathrm{yr}]$ 으로 변환시킨다.

\subsection{5 프로그램 구조}

Fig. 8는 GOLDSIM의 모델링 구조이다. GOLDSIM도 다
른 전산프로그램과 마찬가지로 구획모델로 적용하고 있다. MASCOT에서처럼 개별적인 각 선원항을 모델링하며, 자연 암반으로 누출되기 전에 파쇄대를 적용한 점을 제외하고는 동일한 이동경로를 보여주고 있다.

\subsection{SAFE-ROCK 프로그램}

SAFE-ROCK는 중저준위방사성폐기물의 천층처분시설에 대 한 폐쇄후 안전평가를 위하여 KAERI-KHNP와 미국 Monitor Scientific 사가 공동으로 개발하여 동굴처분시설의 폐쇄후 안전평가를 목적으로 보완한 프로그램이다[6]. 동굴처분시 스템의 각 요소를 통과하는 방사성핵종이동을 평가하기 위 해 근계와 원계모델 구획으로 구분하여 작성되었다.

\subsection{1 선원항}

선원항 모델링을 위해 처분시설을 통과하는 유량은 균 등하고 시간에 따라 일정(steady)하다고 보았으며, 파손 시

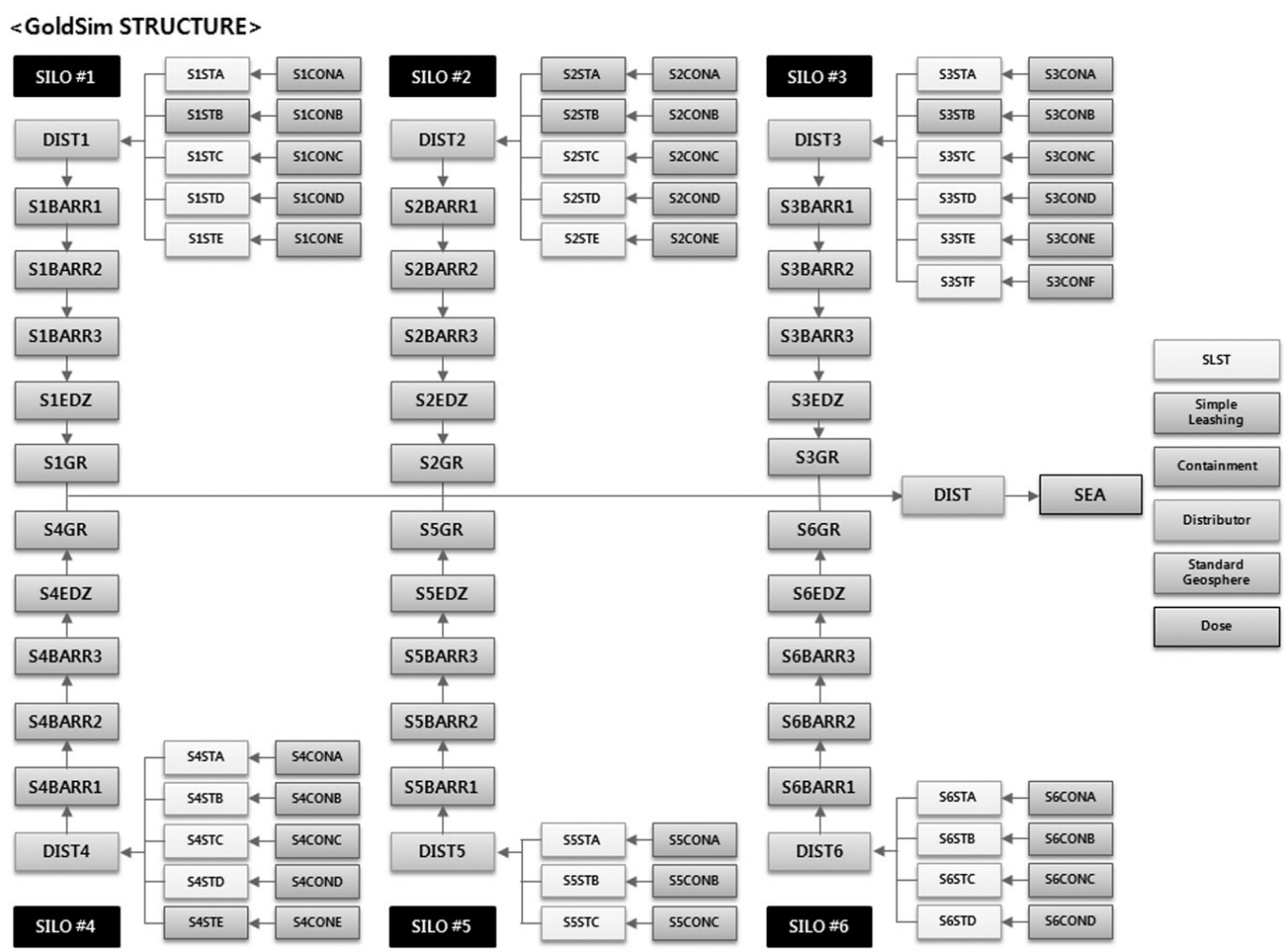

Fig. 8. Modeling Structure of GOLDSIM Program. 
Kang-Il Jung. et al : Concrete Degradation Comparison of Computer Programs for Post-Closure Safety Assessment of Wolsong Low- and Intermediate-Level Radioactive Waste Disposal Facility

작시점 $\left(\mathrm{t}_{\mathrm{fi}}\right)$ 과 완료시점 $\left(\mathrm{t}_{\mathrm{fe}}\right)$ 사이에 처분고 또는 사일로를 포 함한 처분시스템은 유동에 대한 투수성이 생기게 되어 시간 이 경과함에 따라 투수율이 증가한다고 가정하였다. 이러한 수리학적 진행과정은 함수로 표현되며, 이 함수는 시간에 대 한 선형 함수(linear function) 혹은 불연속 단계 함수(piecewise step function)로 개략화되어 있다.

방사성핵종 용해는 총 세 가지의 유형으로 고려되며, 첫 번째 유형으로는 순간용해이며, 이는 MASCOT의 용해도 제 한모델과 동일방식으로 적용된다. 두 번째는 조화용해로, 단 순침출모델과 동일하게 적용하며, 마지막으로 확산누출로 고화된 폐기물 고화체 내 방사성핵종 누출로, 이는 고화체 에서 주변 침투수로의 확산율에 의해 제한되는 모델이다. 처 분구획에서 $\mathrm{i}$ 번째 핵종에 대한 질량보존식은 식 (7)과 같다.

$$
\begin{gathered}
\mathrm{V}_{v} \frac{d A_{v, i}}{d t}=-\lambda_{i} V_{v} A_{v, i}+\lambda_{i-1} V_{v} A_{v, i}+m_{d, 1}^{\cdot}(t) \\
+M_{i}\left(t_{f a i l}\right) f_{s} \delta\left(t_{f a i l}\right)+\frac{M_{i}(t) f_{u, i}}{t_{u}}-q_{n, f}(t) C_{v, i} \\
-T_{V \rightarrow E}\left(C_{v, i}-C_{E, i}\right), t \geq t_{f i}, \quad i=1,2, \ldots . N_{n}
\end{gathered}
$$

여기서 $\mathrm{V}_{\mathrm{v}}$ 는 처분고의 총 체적 $\left[\mathrm{m}^{3}\right], \mathrm{A}_{\mathrm{v}, \mathrm{i}}$ 는 처분고 구획 에서 $\mathrm{i}$ 번째 핵종의 총 농도 $\left[\mathrm{mol} / \mathrm{m}^{3}\right], \lambda$ 는 붕괴상수 $[1 / \mathrm{yr}]$, $\mathrm{m}_{\mathrm{d}, \mathrm{l}}(\mathrm{t})$ 는 확산누출 폐기물 고화체로부터 $\mathrm{i}$ 번째 핵종의 누출 율 $[\mathrm{mol} / \mathrm{yr}], \mathrm{t}_{\mathrm{fi}}$ 는 침투수가 처분고 또는 사일로 내부 폐기 물 고화체와 처음으로 접촉하는 시간 $[\mathrm{yr}], \mathrm{M}_{\mathrm{i}}(\mathrm{t})$ 는 처분고 또 는 사일로 내 $\mathrm{i}$ 번째 핵종의 총 방사능재고량 $[\mathrm{mol}], \mathrm{f}_{\mathrm{s}}$ 는 순간 누출 유형을 갖는 폐기물고화체 내 $i$ 번째 핵종의 분율, $\delta$ 는 $\operatorname{Dirac}$ 델타 함수 $[1 / \mathrm{yr}], \mathrm{f}_{\mathrm{u}, \mathrm{L}}$ 는 균일누출 유형을 갖는 폐기물고 화체 내 $i$ 번째 핵종의 분율, $\dot{q}_{\mathrm{nf}}(\mathrm{t})$ 는 처분고 또는 사일로 침투 수량 $\left[\mathrm{m}^{3} / \mathrm{yr}\right], \mathrm{T}_{\mathrm{v} \rightarrow \mathrm{E}}$ 는 처분고 또는 사일로에서 인공방벽으로 의 확산계수 $\left[\mathrm{m}^{3} / \mathrm{yr}\right], \mathrm{C}_{\mathrm{v}, \mathrm{i}}$ 는 처분고 또는 사일로 내의 지하수 의 핵종 농도 $\left[\mathrm{mol} / \mathrm{m}^{3}\right], \mathrm{C}_{\mathrm{E}, \mathrm{i}}$ 는 인공방벽 내의 지하수의 핵종 농도 $\left[\mathrm{mol} / \mathrm{m}^{3}\right], \mathrm{N}_{\mathrm{n}}$ 은 총 핵종의 수를 나타내고 있다.

\subsection{2 근계지역}

SAFE-ROCK에서는 인공방벽에서의 방사성핵종이동을 모델링하기 위해 근계에서의 이동길이는 상대적으로 짧기 때문에 분산은 무시되며, 고체 구획상의 방사성핵종 흡착반 응은 선형 평형 흡착 모델을 따른다고 가정한다. $j$ 번째 구획

\section{<SAFE-ROCK STRUCTURE>}

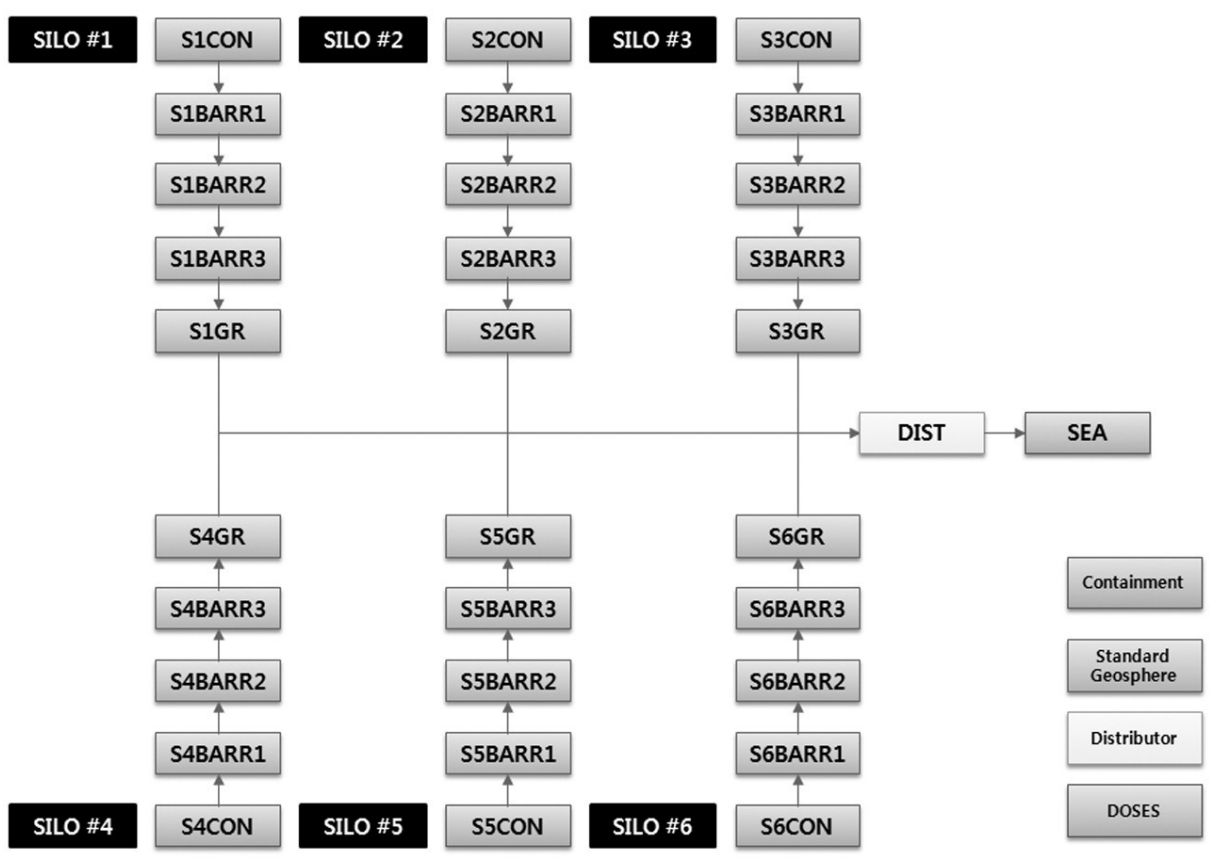

Fig. 9. Modeling Structure of SAFE-ROCK Program. 
Kang-Il Jung. et al : Concrete Degradation Comparison of Computer Programs for Post-Closure Safety Assessment of Wolsong Low- and Intermediate-Level Radioactive Waste Disposal Facility

내의 i번째 핵종에 대한 질량보존식은 식 (8)과 같다.

$$
\begin{gathered}
\text { 초기조건 } \mathrm{A}_{\mathrm{i}, \mathrm{j}}(\mathrm{t}=0)=0 \\
\mathrm{~V}_{\mathrm{v}} \frac{\mathrm{dA}_{\mathrm{v}, \mathrm{i}}}{\mathrm{dt}}=\lambda_{\mathrm{i}-1} \mathrm{~V}_{\mathrm{j}} \mathrm{A}_{\mathrm{i}, \mathrm{j}}-\lambda_{\mathrm{i}} \mathrm{V}_{\mathrm{j}} \mathrm{A}_{\mathrm{i}, \mathrm{j}}+\left[\mathrm{T}_{\mathrm{j}-1} \mathrm{~m}_{\mathrm{d}, 1 \rightarrow \mathrm{j}}\left(\mathrm{C}_{\mathrm{i}, \mathrm{j}-1}-\mathrm{C}_{\mathrm{i}, \mathrm{j}}\right)\right. \\
\left.+\dot{\mathrm{q}} \mathrm{C}_{\mathrm{i}, \mathrm{j}-1}\right]-\left[\mathrm{T}_{\mathrm{j} \rightarrow \mathrm{j}+1}\left(\mathrm{C}_{\mathrm{i}, \mathrm{j}-1}-\mathrm{C}_{\mathrm{i}, \mathrm{j}+1}\right)+\dot{\mathrm{q}}_{\mathrm{i}, \mathrm{j}-1}\right] \mathrm{t}>\mathrm{t}_{\mathrm{fi}}
\end{gathered}
$$

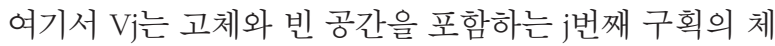
적 $[\mathrm{m} 3], \mathrm{A}_{\mathrm{i}, \mathrm{j}}$ 는 이 구획에서 $\mathrm{i}$ 번째 핵종의 총 농도 $\left[\mathrm{mol} / \mathrm{m}^{3}\right]$,

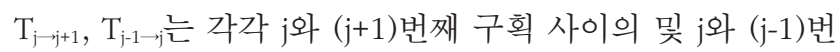
째 구획 사이의 질량전달계수(mass transfer coefficient) [m³ $\mathrm{yr}], \mathrm{C}_{\mathrm{i}, \mathrm{j}}$ 는 구획 내의 핵종에 대한 수용성 농도(aqueous concentration) $\left[\mathrm{mol} / \mathrm{m}^{3}\right]$ 이다.

\subsection{3 원계지역}

방사성핵종의 이동양상은 매질의 종류에 따라 결정되며, 원계지역 모델링에서는 다공성 암반을 매질로 고려하였으 며, 분자 확산과 종분산(longitudinal dispersion)은 이류 선 단(advection front)에 앞서서 방사성핵종 plume을 확산시 키며, 방사성핵종은 포화대에서 흡착되고, 지하수는 일정한 속도로 수평적으로 흐른다고 가정하였다. 또한, 방사성핵종 이 용해도 제한을 받으며 근계를 떠나 원계에서 일정하고 균 일하며, 방사성핵종의 흡착은 선형평형모델(linear equilibrium model)을 따르고 공극률, 흡착계수, 확산/분산계수 등의 입력변수들은 원계 내에서 일정하고 균일하다고 가정하였다.

또한, 원계의 마지막 경계 부분에서의 농도는 0 인 것으로 가정한다. 이 조건은 생태계와의 경계부분에서 누출량(flux)
을 과대 평가하는 경향이 있으나 확산보다 이류가 지배적으 로 일어날 경우 이러한 가정은 큰 영향을 주지 않는다. 포화 암반에서의 핵종이동 방정식은 식 (9)과 같다.

$$
\begin{gathered}
V_{i} \frac{d A_{i}}{d t}=\lambda_{p} V_{j} A_{i, p}-\lambda V_{j} A_{i}+\left[T_{i-1}\left(C_{i-1}-C_{i}\right)+v_{f f} \alpha_{i-1 \rightarrow i}\right. \\
\left.C_{i-1}\right]-\left[T_{1 \rightarrow i+1}\left(C_{i}-C_{i+1}\right)+v_{f f} \alpha_{i \rightarrow i+1}\right] \quad t>t_{\text {fail }}
\end{gathered}
$$

여기서 $\mathrm{V}_{\mathrm{i}}$ 는 $\mathrm{i}$ 번째 구획의 체적 $\left[\mathrm{m}^{3}\right], \mathrm{A}_{\mathrm{i}}$ 는 $\mathrm{i}$ 번째 구획에서 의 핵종의 총 농도 $\left[\mathrm{mol} / \mathrm{m}^{3}\right], \lambda$ 는 붕괴상수 $[1 / \mathrm{yr}], " P^{\prime \prime}$ 는 모 핵종(parent nuclide), $\mathrm{C}_{\mathrm{i}}$ 는 i번째 구획에서의 핵종에 대한 수 용액 농도(aqueous concentration) $\left[\mathrm{mol} / \mathrm{m}^{3}\right], \mathrm{v}_{\mathrm{ff}}$ 는 포화대의 $\operatorname{Darcy}$ 속도 $[\mathrm{m} / \mathrm{yr}], \alpha$ 는 두 개의 인접 구획 사이의 경계면적 $\left[\mathrm{m}^{2}\right]$ 을 나타내고 있다.

\subsection{4 생태계}

생태계 단위 모델에서는 각 핵종 별 누출량 $[\mathrm{Bq} / \mathrm{yr}]$ 을 생 태계 평가모델에서부터 평가된 선량환산인자 $[\mathrm{Sv} / \mathrm{Bq}]$ 을 통 해 선량 $[\mathrm{Sv} / \mathrm{yr}]$ 으로 변환시킨다.

\subsection{5 프로그램 구조}

SAFE-ROCK의 프로그램 구조를 Fig. 9와 같이 표현하였 다. MASCOT와 같이 SAFE-ROCK도 구획 모델을 적용한다. MASCOT에서 선원항을 각 사일로의 폐기물의 형태에 맞는 누출모델로 구분하였지만, SAFE-ROCK는 사일로 한 개당 하 나의 선원항으로만 누출모델을 표현한다. 누출경로는 폐기 물 $($ Waste forms) $\rightarrow$ 처분용기(Overpack) $\rightarrow$ 쇄석 (Crushed

Table 1. Input Parameter of Post-Closure Safety Assessment Program (INVENTORY)

\begin{tabular}{ccccccc}
\hline Inventory $(\mathrm{Bq})$ & Silo1 & Silo2 & Silo3 & Silo4 & Silo5 & Silo6 \\
\hline${ }^{3} \mathrm{H}$ & $3.10 \mathrm{E}+14$ & $1.04 \mathrm{E}+14$ & $3.44 \mathrm{E}+14$ & $1.12 \mathrm{E}+14$ & $7.77 \mathrm{E}+13$ & $1.83 \mathrm{E}+14$ \\
\hline${ }^{14} \mathrm{C}$ & $4.01 \mathrm{E}+13$ & $1.66 \mathrm{E}+13$ & $3.62 \mathrm{E}+13$ & $7.30 \mathrm{E}+12$ & $3.17 \mathrm{E}+13$ & $2.76 \mathrm{E}+12$ \\
\hline${ }^{59} \mathrm{Ni}$ & $6.40 \mathrm{E}+12$ & $1.14 \mathrm{E}+13$ & $3.79 \mathrm{E}+12$ & $1.12 \mathrm{E}+12$ & $1.34 \mathrm{E}+12$ & $2.38 \mathrm{E}+12$ \\
\hline${ }^{94} \mathrm{Nb}$ & $2.83 \mathrm{E}+10$ & $2.12 \mathrm{E}+10$ & $9.09 \mathrm{E}+09$ & $7.80 \mathrm{E}+09$ & $9.79 \mathrm{E}+09$ & $6.28 \mathrm{E}+09$ \\
\hline${ }^{99} \mathrm{Tc}$ & $5.99 \mathrm{E}+10$ & $4.36 \mathrm{E}+10$ & $7.73 \mathrm{E}+10$ & $2.98 \mathrm{E}+10$ & $3.57 \mathrm{E}+11$ & $2.53 \mathrm{E}+10$ \\
\hline${ }^{129} \mathrm{I}$ & $2.15 \mathrm{E}+08$ & $1.76 \mathrm{E}+07$ & $5.08 \mathrm{E}+08$ & $1.26 \mathrm{E}+07$ & $6.58 \mathrm{E}+07$ & $2.14 \mathrm{E}+07$ \\
\hline Alpha & $3.14 \mathrm{E}+11$ & $1.12 \mathrm{E}+10$ & $1.09 \mathrm{E}+11$ & $4.29 \mathrm{E}+09$ & $4.42 \mathrm{E}+10$ & $2.23 \mathrm{E}+10$ \\
\hline
\end{tabular}


Kang-Il Jung. et al : Concrete Degradation Comparison of Computer Programs for Post-Closure Safety Assessment of Wolsong Low- and Intermediate-Level Radioactive Waste Disposal Facility

Table 2. Input Parameter of Post-Closure Safety Assessment Program (Kd)

\begin{tabular}{|c|c|c|c|c|c|c|}
\hline $\mathrm{Kd}\left(\mathrm{m}^{3} / \mathrm{kg}\right)$ & Waste & Drum & Backfill & $\begin{array}{l}\text { Concrete } \\
\text { (Before } \\
\text { degradation) }\end{array}$ & $\begin{array}{c}\text { Concrete } \\
\text { (After } \\
\text { degradation) }\end{array}$ & Granite \\
\hline${ }^{3} \mathrm{H}$ & 0 & 0 & 0 & 0 & 0 & 0 \\
\hline${ }^{14} \mathrm{C}$ & $1.44 \mathrm{E}-03$ & $1.44 \mathrm{E}-03$ & $1.44 \mathrm{E}-03$ & $5.00 \mathrm{E}-02$ & $1.44 \mathrm{E}-03$ & $2.50 \mathrm{E}-03$ \\
\hline${ }^{59} \mathrm{Ni}$ & $1.60 \mathrm{E}-01$ & $1.60 \mathrm{E}-01$ & $1.60 \mathrm{E}-01$ & $5.00 \mathrm{E}-01$ & $1.60 \mathrm{E}-01$ & $3.50 \mathrm{E}-02$ \\
\hline${ }^{94} \mathrm{Nb}$ & $1.23 \mathrm{E}+00$ & $1.23 \mathrm{E}+00$ & $1.23 \mathrm{E}+00$ & $5.00 \mathrm{E}-02$ & $1.23 \mathrm{E}+00$ & $1.38 \mathrm{E}-01$ \\
\hline${ }^{99} \mathrm{Tc}$ & 0 & 0 & 0 & 0 & 0 & $1.00 \mathrm{E}-03$ \\
\hline${ }^{129} \mathrm{I}$ & 0 & 0 & 0 & $1.00 \mathrm{E}-03$ & 0 & 0 \\
\hline Alpha & $1.39 \mathrm{E}+01$ & $1.39 \mathrm{E}+01$ & $1.39 \mathrm{E}+01$ & $1.00 \mathrm{E}+00$ & $1.39 \mathrm{E}+01$ & $1.18 \mathrm{E}+00$ \\
\hline
\end{tabular}

Table 3. Input Parameter of Post-Closure Safety Assessment Program (Porosity/Density/ Effective Diffusivity/ Hydraulic Conductivity)

\begin{tabular}{lcccc}
\hline & Porosity(-) & Density $\left(\mathrm{kg} / \mathrm{m}^{3}\right)$ & $\begin{array}{c}\text { Effective } \\
\text { Diffusivity } \\
\left(\mathrm{m}^{2} / \mathrm{s}\right)\end{array}$ & $\begin{array}{c}\text { Hydraulic } \\
\text { Conductivity } \\
(\mathrm{m} / \mathrm{s})\end{array}$ \\
\hline Drum & 0.3 & 1890 & $6.00 \mathrm{E}-10$ & $1.00 \mathrm{E}-04$ \\
\hline Backfill & 0.45 & 1890 & $6.00 \mathrm{E}-10$ & $1.00 \mathrm{E}-04$ \\
\hline Concrete (Before degradation) & 0.1 & 2389 & $1.00 \mathrm{E}-11$ & $6.47 \mathrm{E}-12$ \\
\hline Concrete (After degradation) & 0.3 & 1890 & $6.00 \mathrm{E}-10$ & $1.00 \mathrm{E}-04$ \\
\hline Granite & $2.70 \mathrm{E}-03$ & 2590 & $3.10 \mathrm{E}-13$ & $6.00 \mathrm{E}-08$ \\
\hline
\end{tabular}

rock) $\longrightarrow$ 사일로 (Concrete lining) $\longrightarrow$ 자연방벽 (Granite) $\longrightarrow$ 생태계(Biosphere)로 구획화하였다.

\section{4. 상호비교를 위한 문제 설정}

세 가지의 폐쇄후 안전평가 프로그램에 대한 신뢰성을 확보하기 위해서, 동일한 시나리오에 대해 동일한 입력값을 적용하여 결과값을 비교/분석하였다. 본 논문에서는 방사성 핵종이 폐기물에 침투한 지하수에 의해 용해되며, 용해된 핵 종은 폐기물포장물, 처분용기, 뒷채움재, 콘크리트 사일로를 통해 원계지역으로 이동하며, 또 다시 생태계로 이동하는 정 상시나리오를 선정하였다.

콘크리트 열화시점을 처분시설 폐쇄 후 1645년 이후에 콘크리트 구조물이 완전히 열화 되는 것으로 모델링에 반영 하였다. 또한, 총 6 개 사일로에 처분된 1단계 폐기물 부피 기준 $35,200 \mathrm{~m}^{3}$ (포장물 단위 10 만 개)에 대하여 고려하였다.

일반적으로 방사성핵종은 공학적 방벽과 자연방벽을 통 해 생태계로 핵종누출을 제한하게 된다. 공학적방벽은 폐기
물포장물, 처분용기, 뒷채움재, 콘크리트사일로 방벽으로 구 성되며, 자연방벽은 천연암반으로 구성하였다.

MASCOT 프로그램을 이용한 폐쇄 후 안전평가 모델링 에서는 콘크리트사일로 방벽의 열화 이후 처분용기의 연속 적인 열화를 적용하지 않았으며, 폐쇄후 지하수를 통한 핵종 누출 평가에서는 콘크리트 열화기간 동안 선형적인 콘크리 트 방벽의 특성변화를 고려하지 않고 자연 열화시점 이후에 는 방벽역할을 상실하는 것으로 가정하였다.

Table 1은 폐쇄 후 안전평가 프로그램에 입력되는 사일 로 별 핵종재고량을 나열하였으며, Table 2은 각 구획 별로 입력되는 핵종별 분배계수를 나열하였다. Table 3 에서는 구 획별로 입력되는 공극률, 밀도, 유효확산계수, 수리전도도를 각각 나열하였다.

\section{5. 상호비교를 위한 문제의 결과 및 고찰}

설정된 문제에 대하여 각 프로그램을 이용하여 평가하 였다. Fig. 10은 각 프로그램을 이용한 정상시나리오의 선량 
Kang-Il Jung. et al : Concrete Degradation Comparison of Computer Programs for Post-Closure Safety Assessment of Wolsong Low- and Intermediate-Level Radioactive Waste Disposal Facility

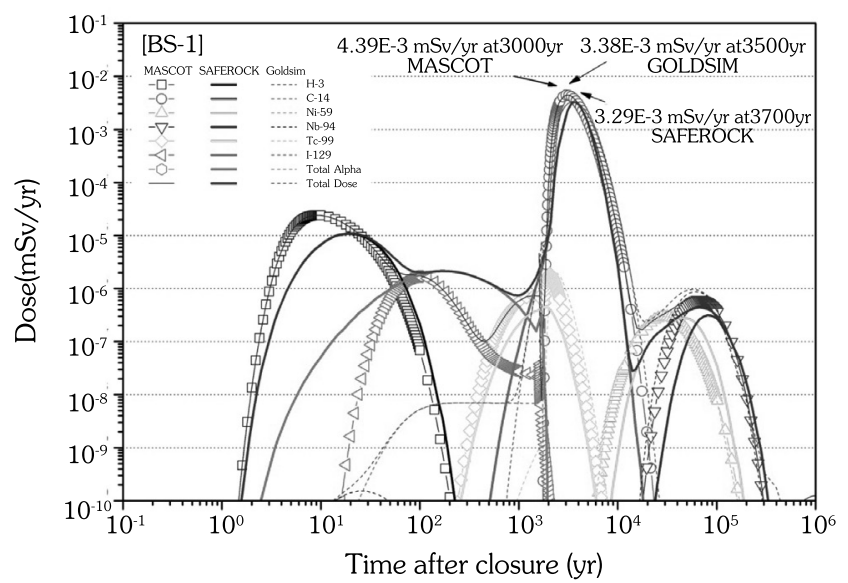

Fig. 10. Expected Dose Result of Post-Closure Safety Assessment Programs(Normal scenario [BS-1]).

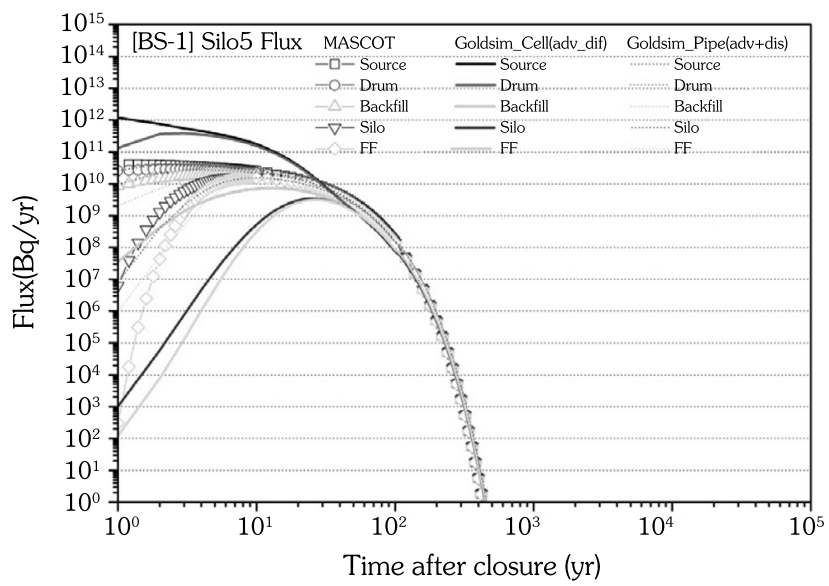

Fig. 11. Comparison of the ${ }^{3} \mathrm{H}$ Results of MASCOT, GOLDSIM(Cell Pathway)and GOLDSIM(Pipe Pathway) on Normal scenario [BS-1].

평가 결과를 나타내었다. ${ }^{3} \mathrm{H}$ 과 ${ }^{129} \mathrm{I}$ 핵종의 경우, 열화시점 이 전에 MASCOT와 SAFE-ROCK에서는 유사한 경향을 나타내 지만, GOLDSIM에서는 다른 경향을 나타내고 있다.

프로그램별 추가 분석을 위해, ${ }^{3} \mathrm{H}$ 핵종을 대상으로 사 일로 5번에 대해서 MASCOT와 GOLDSIM을 이용하여 각 구 획별로의 누출량을 평가하였다. GOLDSIM의 경우 근계모델 에 쓰인 cell pathway를 적용하여 누출량을 평가하였을 때, MASCOT와는 다른 결과를 보여주었으며, 이에 따라 일반적 으로 원계에서 쓰이는 Pipe pathway를 근계지역에서 적용하 여 구획별로 누출량을 평가해 보았다.

Fig. 11에서는 근계지역의 MASCOT의 결과는 GOLDSIM

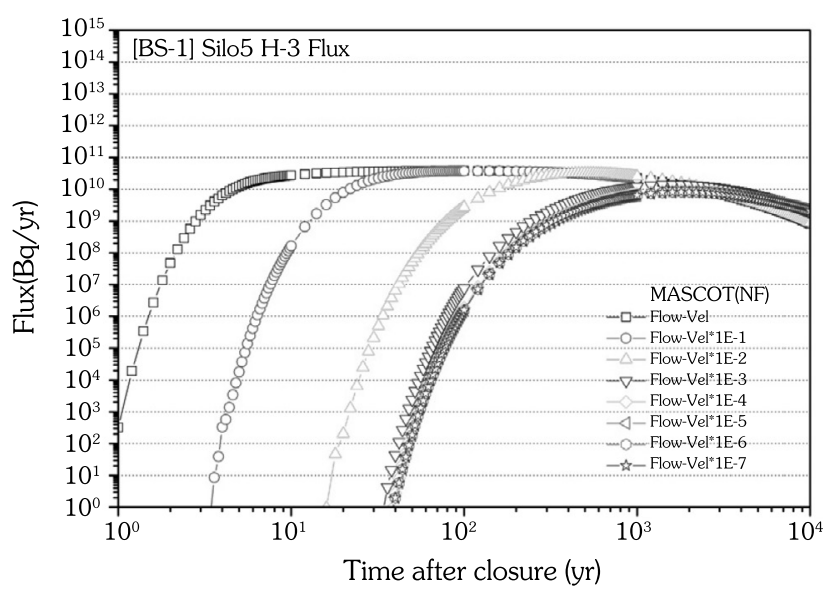

Fig. 12. Comparison of the ${ }^{3} \mathrm{H}$ (modified Half-life:1.233E8) Results of Various Flow velocity in MASCOT on Normal scenario [BS-1].

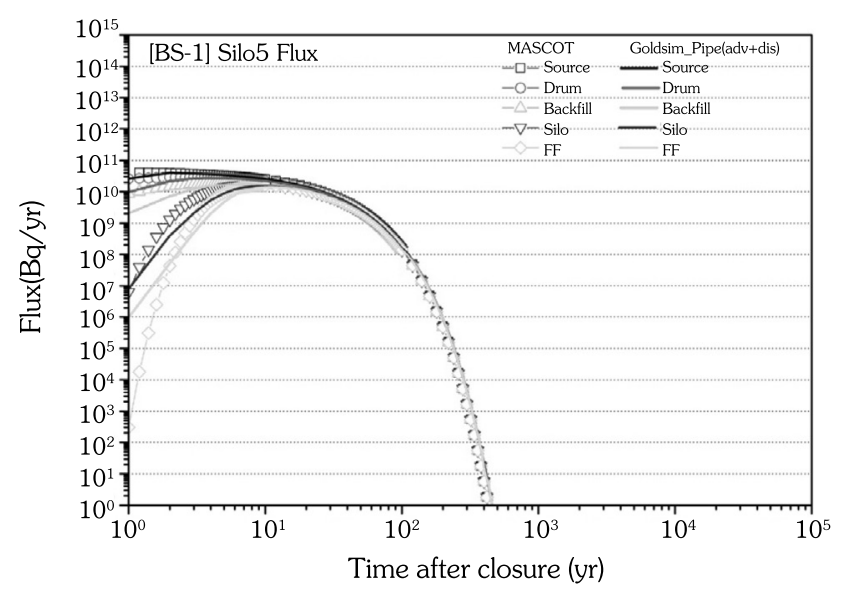

Fig. 13. Comparison of the ${ }^{3} \mathrm{H}$ Results of MASCOT and GOLDSIM(Pipe pathway) on Normal scenario [BS-1].

의 근계지역의 Cell pathway로 모델링하였을 때보다 원계지역의 Pipe pathway로 표현할 때에 가장 유사한 경향을 나타내고 있다. 그 이유로 MASCOT와 GOLDSIM 의 Pipe pathway는 모두 핵종이동 방정식을 푸는 방식이 Laplace 변환방법으로 동일하기 때문이다.

또한, Laplace 변환방법을 통한 핵종이동 방정식을 평 가할 때 이류와 확산을 고르게 반영하는지 확인하기 위하 여 근계지역에서 나오는 ${ }^{3} \mathrm{H}$ 의 반감기(12.3년)를 장반감기 $(1.233 \mathrm{E}+8$ 년 $)$ 로 변경하여 방사성붕괴 현상으로 사라지는 핵 종재고량을 인위적으로 배제하였다. 먼저 이류현상의 대표 적인 인자인 지하수 유동속도를 0 으로 설정하여 평가한 결 
Kang-Il Jung. et al : Concrete Degradation Comparison of Computer Programs for Post-Closure Safety Assessment of Wolsong Low- and Intermediate-Level Radioactive Waste Disposal Facility

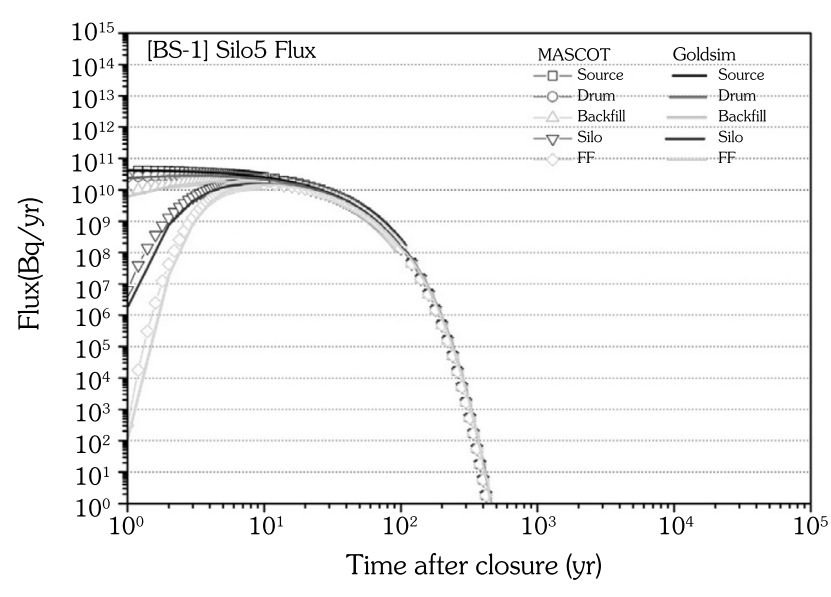

Fig. 14. Comparison of the ${ }^{3} \mathrm{H}$ Revised Results of MASCOT and GOLDSIM(Pipe Pathway) on Normal scenario [BS-1].

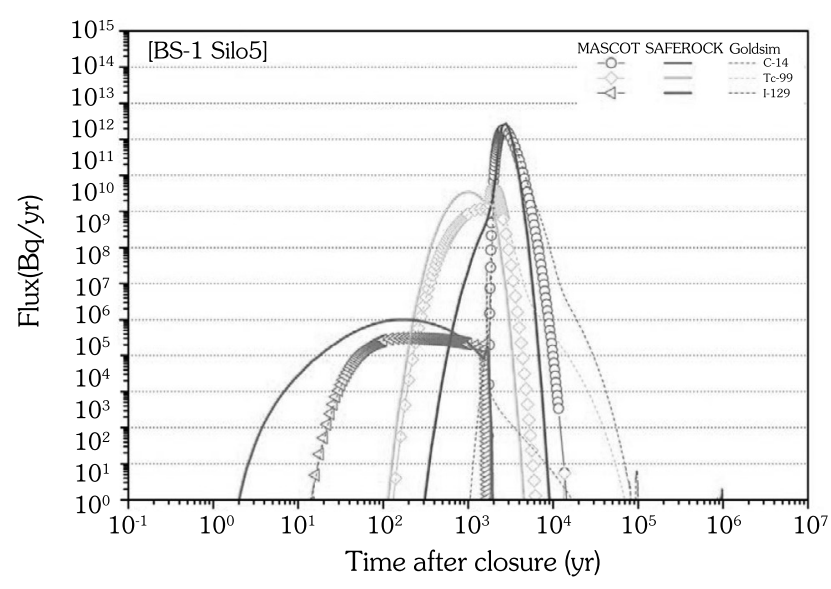

Fig. 15. Flux $\left({ }^{14} \mathrm{C},{ }^{99} \mathrm{Tc},{ }^{129} \mathrm{I}\right)$ Result of Silo 5 on Normal scenario [BS-1].

과, 선량 및 누출량이 평가되지 않았다. 하지만, 확산의 대표 적인 인자인 유효확산계수를 0 으로 설정하여도 선량과 누출 량에 대해서는 평가를 수행할 수 있다.

이에 따라 유동속도를 다양하게 나누어 평가를 수행하였 을 때, Fig. 12와 같이 그에 따라 MASCOT의 공학적방벽에 서의 유동속도를 나누어 계산해본 결과 일정속도 이하로 뗠 어지게 되면 누출량의 결과가 수렴하게 되는 걸 알 수 있다. 공학적방벽에서의 핵종이동 방정식은 식 (3)과 같은 방식으 로 풀어가는데, 유동속도가 무시할 만큼 작아지게 되면 분산 이 지배적이다.
결과적으로 MASCOT에서의 핵종이동 방정식을 평가하 는데 분산보다는 이류가 지배적으로 적용되며, MASCOT 프 로그램 특성상 유효확산계수와 달리 유동속도가 0 으로 설정 되면 다음 구획으로 누출량을 보내지 않는 것으로 판단되어 평가를 수행할 수가 없었다.

MASCOT 모델링에서는 Laplace 변환법을 통해 핵종이 동 방정식을 평가함으로 확산보다는 이류에 영향을 많이 반 영하여 평가하는 걸로 판단되며, 이에 따라 이류가 존재하지 않은 환경에서는 MASCOT 평가방법이 적합하지 않다고 판 단된다.

Fig. 13에서는 MASCOT와 GOLDSIM의 Pipe pathway로 핵종누출량을 비교하였다. 폐기물에서부터 핵종 초기 누출 량은 다르게 표현되는데, 이는 프로그램별 누출량의 Timescale을 다르게 평가하여서 폐기물에서의 초기 누출량이 다 르게 나타났다.

이에 각 프로그램의 Time-scale를 유사하게 설정하여 초 기 누출량을 비교해보니, Fig. 14와 같이 각 프로그램의 시간 에 따른 누출량이 유사하게 나타났다. 결과적으로는 다른 핵 종들과 달리 ${ }^{3} \mathrm{H}$ 핵종과 같이 단반감기(12.3 년)이며 흡착계 수가 매우 적은 핵종은 어떤 범위로 Time-scale을 나누느냐 에 따라 초기 핵종누출량에 영향을 받고 있음을 알 수 있다.

또한 ${ }^{129} \mathrm{I}$ 의 경우, 열화시점 이후에도 누출되는 핵종으로, 각 프로그램의 콘크리트 열화시점에 대한 평가방법이 달라 모두 다른 결과값을 보여주고 있다. MASCOT의 경우 콘크리 트 열화시점에 핵종들이 한꺼번에 누출된다고 가정하고, 열 화시점 이전의 핵종재고량을 평가하여 초기 핵종재고량와 비교하여 열화시점 이전까지 핵종누출량을 평가한 후 열화 시점 이후의 재고량에 적용하여 평가한다.

SAFE-ROCK의 경우 처분용기의 연속적인 열화를 적용 하여, 열화시점(1,645 년)과 열화 완료시점(1,645.01 년) 사 이에 지하수의 침투율을 선형적인 함수로 표현된다고 가정 한다. 또한, 근계지역의 핵종누출에서 식 (7)처럼 이루어지 는데 확산누출, 순간누출, 균일누출, 이류까지 모두 반영함 으로써, 누출의 시점이 다른 프로그램에 비해 일찍 나타나는 걸로 판단된다. GOLDSIM 경우 MASCOT처럼 열화전·후의 재고량을 재계산하지 않고 연속적으로 핵종재고량에 대하여 평가를 수행할 수 있다. 이처럼 각 프로그램에 따른 열화시점 평가방법이 다르므로, 다른 결과값을 보여주고 있다.

이에 사일로 5 번에 대해서만 열화시점 이후에도 누출되 는 핵종을 GOLDSIM(근계지역에 Pipe pathway 적용 시)과 MASCOT, SAFFE-ROCK를 이용하여 누출량을 평가한 결과, 
Kang-Il Jung. et al : Concrete Degradation Comparison of Computer Programs for Post-Closure Safety Assessment of Wolsong Low- and Intermediate-Level Radioactive Waste Disposal Facility

Fig. 15와 같이 열화시점 이전까지는 MASCOT와 GOLDSIM 의 경향은 유사하게 나타나지만, 열화시점 이후의 핵종에 대 한 누출시간이 MASCOT나 SAFE-ROCK과 달리 GOLDSIM에 서는 선원항부터 열화시점 당시 지점까지 재고량을 반영하 는 만큼 핵종누출시간이 늘어나는 경향을 볼 수 있다.

\section{6. 결론}

본 논문에서는 폐쇄 후 안전평가에 사용되는 컴퓨터 프 로그램의 신뢰성을 확보하기 위해 프로그램으로써 사용된 MASCOT와 검증프로그램으로 SAFE-ROCK와 GOLDSIM을 선정하여 정상시나리오에 대하여 안전평가를 수행하였다. 각 프로그램의 장단점을 비교/분석하였으며, 각 프로그램별 구획간의 선량 및 누출량을 평가하였다. 그 중 방사성핵종 ${ }^{129} \mathrm{I}$ 와 ${ }^{3} \mathrm{H}$ 가 MASCOT와 SAFE-ROCK 프로그램에서는 비슷한 경향을 보여주었지만, GOLDSIM 프로그램에서는 상이한 결 과를 나타냈다.

정확한 분석을 위해 프로그램에 따른 구획별로 누출량을 평가해 보았을 때, 근계지역에서 누출되는 핵종 $\left({ }^{3} \mathrm{H},{ }^{129} \mathrm{I}\right)$ 에 대한 이류와 수리분산이 지배되는 조건하에 거동하기 때문 에, 핵종거동에 이류와 분산이 고르게 반영되어야 한다. 그 러나 각 프로그램의 근계지역 내 핵종이동방정식의 해석과 정이 확산보다 이류를 지배적으로 반영하는 것과 ${ }^{129} \mathrm{I}$ 같은 경 우, 열화시점 이후에도 누출되는 핵종으로 근계지역의 핵종 이동방정식의 해석과정의 차이와 함께 열화시점에 대한 평 가시 MASCOT에서는 연속적인 방정식을 적용하지 못하는 프로그램의 한계로 인해 다른 결과를 보여주었다. 추가적으 로 GOLDSIM 프로그램의 경우, 선원항 구획에서의 초기 핵 종누출량은 time-scale에 민감하게 반응한다는 사실도 알게 되었다. 그 외의 핵종 같은 경우 대부분의 결과값이 콘크리트 열화시점 이후부터 사용자가 원하는 평가범위안에 나타나고 있으며, 이는 원계지역에서 핵종누출이 근계지역보다 영향 력이 크다고 볼 수 있다. GOLDSIM과 MASCOT의 원계지역 에서 핵종누출이 Laplace 변환법으로 동일하게 사용함으로 써 콘크리트 열화시점 이후의 핵종에 대해서는 GOLDSIM과 MASCOT가 유사하게 평가되었다.

따라서 MASCOT와 SAFE-ROCK는 실제 지하수에서 일 어나는 방사성핵종 거동을 단순히 모사하여 평가하는 모델 로서 이류-분산 이동방정식을 uniform한 1차원적 유동으로 만 가정하여 핵종거동을 평가한다. 또한 MASCOT의 경우, 추가적인 열화후의 재고량 적용 및 근계지역의 확산보다는
이류를 지배적으로 반영하는 단점을 가지고 있다.

안전평가 프로그램은 처분환경에서 발생하는 핵종거동 및 이동에 대한 실제현상을 예측하기 위해 모델링을 거치지 만, 전산프로그램의 특성과 실제현상에 대한 데이터가 제한 적이므로 결과에 차이가 발생하게 된다. 이러한 차이점은 다 양한 프로그램을 이용한 결과와 상호비교를 통해 알아내며 그 원인을 지속적으로 분석하는 연구개발과정을 필요로 하 고 있다.

향후, GOLDSIM와 MASCOT의 근계지역의 핵종이동에 대한 정확한 평가를 위해 GOLDSIM의 근계지역 평가에 사용 되는 Cell pathway 개수에 따른 합리적인 설정 및 검증과 더 불어 추가 입력변수의 수집 및 다른 시나리오를 수행하면서 각 프로그램의 핵종이동 모델링 보완을 꾸준히 수행할 계획 이다. 또한 천층처분시설 안전성평가를 위한 천층처분에 대 한 핵종이동 모델링도 구축할 계획을 가지고 있다.

\section{REFERENCES}

[1] Nuclear Safety and Security Commission Notice, No 2013-36, Guidelines for Preparation of Safety Analysis Report for Low- and Intermediate-Level Radioactive Waste Disposal Facilities, Nuclear Safety and Security Commission (2013).

[2] Nuclear Safety and Security Commission Notice, No 2013-35, Technical Requirements for the Operation and Control of Low-Intermediate-Level Radioactive Waste Disposal Facilities, Nuclear Safety and Security Commission (2013).

[3] Safety Assessment Methodologies for Near Surface Disposal Facilities, Vol. 1, IAEA, Vienna (2004).

[4] J.B. Park, H.R. Jung, E.Y. Lee, C.L. Kim, G.Y. Kim, K.S. Kim, Y.K. Koh, K.W. Park, J.H. Cheong, C.W. Jeong, J.S. Choi, and K.D. Kim, "Wolsong Low- and Intermediate-level Radioactive Waste Disposal Center: Progress and Challenges," Nuclear Engineering and Technology, 41(4), pp. 1-16, May (2009).

[5] J.B. Park, S.I. Cho, and C.L. Kim, "Development of Safety Cases for the Wolsong LILW Disposal Center," 2008 East Asia Forum on Radwaste Management (2008 EAFORM), 20-23 Oct., Tokyo (2008). 
Kang-Il Jung. et al : Concrete Degradation Comparison of Computer Programs for Post-Closure Safety Assessment of Wolsong Low- and Intermediate-Level Radioactive Waste Disposal Facility

[6] J.B. Park, J.W. Park, and C.L. Kim, "Development of Post Closure Safety Assessment Scenario for the Korean LILW Disposal Facility,"2007 International Symposium on Radiation Safety Management, Nov. 7 9, Daejeon (2007).

[7] J.B. Park, K.K. Lee, and E.Y. Lee, "Experience from siting and design of the wolsong Low- and Intermediate-level radioactive waste disposal center in Korea," International special session on radioactive wastes disposal technologies, 2011 Abstracts of Proceeding of the Korean Radioactive Waste Society Autumn, 10. 13 14, Jeju (2011).

[8] J.E. Sinclair and P. J. Agg, MASCOT and MOP Programs for Probabilistic Safety Assessment Part A: Overview, Version 3C/3A, AEA Technology, Harwell, U.K, (1994).

[9] AMBER 4.4, Reference Guide, Enviros, U.K(2002).

[10] GOLDSIM Contaminant Transport Module, User's Guide, Version 5, GOLDSIM Technology Group, Seattle, USA (2006).

[11] J.W. Park, Y.M. Lee, C.H. Kang, C.L. Kim, W. Zhou, and M.W. Kozak, Development of SAGE and QUARK: The computer program and database for the Korean concept for LILW waste disposal safety assessment, Report MSCI-2212-7, Monitor Scientific LLC, USA (2003).

[12] Nuclear Safety and Security Commission Notice, No. 2012-55, Radiological Protection Criteria for Long-term Safety on Low-and Intermediate-Level Radioactive Waste Disposal, Nuclear Safety and Security Commission (2012).

[13] Y.M. Lee, C.H. Kang, Y.S. Hwang, and S.H. Lee, In Depth Modeling of Nuclide Transport in the Geosphere and the Biosphere to Reduce Uncertainty (Final Report). KAERI/CR-365/2010, KEARI (2010).

[14] Y.M. Lee and Y.S. Hwang, Development of a GOLDSIM Biosphere Model, Evaluation, and Its Verification. KAERI/TR-3987/2009, KEARI (2009). 